\title{
Use of Virtual Reality in Teaching Fractions at Elementary Level
}

\author{
Elena Fabiola Ruiz Ledesma \\ Sección de Estudios de Posgrado \\ ESCOM - IPN \\ Mexico City, Mexico \\ efruiz@ipn.mx
}

\author{
Abiel Tomás Parra Hernández) \\ Sección de Estudios de Posgrado \\ ESCOM - IPN \\ Mexico City, Mexico \\ abiel.parra@yahoo.com.mx
}

\begin{abstract}
The learning difficulties of the mathematical concept of fraction is a topic that has been studied by different mathematical educators, but still is a relevant topic today, because despite the proposals that have been made to improve learning, they have not been used for all teachers besides those few that are involved in the use of the technology. Besides that there is little educational software that is based on research and is validated to be taken to the classroom. This article shows a virtual system that has been created for the student to interact with it in order to connect his knowledge with his play skills, skills of discovery, reasoning, communication among others and may have a significant learning of fraction.
\end{abstract}

Keywords - learning, elementary education, technology, virtual reality.

\section{INTRODUCTION}

It is hard learning fractions with natural numbers for elementary school children, students see fractions as a pair of numbers, one on top of another, which are meaningless. [1], [2]. Although the "Secretaría de Educación Pública" in the 2011 program [3] states that students solve different problems according to their school reality with the use of fractions, the test results as performed by the "Evaluación Nacional del Logro en Centros Escolares" (ENLACE,), [4], cast disapproving results in this topic.

Some of the reasons why this problem occurs, deal directly with the ignorance of the meaning of how fractions operate, designing unclear situations by the teacher, poor reading comprehension of different problems by the student [1], [2], [5]-[7]. Besides the lack of interest in it, the lack of imagination of the student to be able to make a sketch of the problem, insufficient time for teaching the subject and little or no support from parents.

For the above reasons this work focused on supporting learning of fractions, particularly the concepts of partition and distribution to primary school students, a system was designed using the methodology Metric 3.0, which allows the student to learn the topic of fractions, by observing actual problems with the use of virtual reality (Sherman and Craig, 2010). Worked subjects were:

- Partition

- Distribution

\section{RESEARCH QUESTION}

How much intervention in the teaching and learning of fractions in partition situations through "Didactic Scenarios" and the use of virtual reality helps notions acquisition necessary for the understanding of the fraction?.

\section{JUSTIFICATION}

In Mexico, Educational Reform was implemented, [8], one of its objectives is to attack the difficulties in understanding mathematics, as given in the case of learning fractions. But which resources has the teacher that help him/her plan lessons and meet the objective of this reform?

For that purpose it was also created a virtual system, which is based on the design of a proposal for teaching fraction through Didactic Scenarios, [9]. Giving guideline to interrelate two disciplines, education in mathematics and computer science.

It is intended that the virtual system be a complementary tool, supporting the learning of the fraction, especially in the concepts of partition and distribution to elementary school children, a methodology is proposed which allows the student to learn fractions by observing real issues with the use of virtual reality. The system increases the complexity of the problems and how the student is assessed. Problems addressed fraction as part-whole, the partition and distribution.

\section{THEORETICAL AsPeCtS}

\section{A. Studies of ICT for teaching}

Currently, in the educational context is possible to design and develop interactive technological materials.

Some results of research state that computer science programs can support the construction of mathematical knowledge in students. As is the case of Ruiz [10].

Harris, [11] states that technology gives the teacher more flexibility to meet the different needs of students with different levels of skills, who may be sharing the same class, using software that can be adapted to the teaching and learning as well as to the particular conditions of each student or group. 
While in traditional education the teacher gives a lesson at certain speed and level. Technology allows the teacher to divide the group into teams and work with everyone at their own pace.

Meanwhile, Galbraith and Haines [12], indicate that multimedia tools allow the use of audio, images, graphics, animation and videos, which are much more efficient than linear media (like books) to capture the interest of students and increase their educational process. Multimedia allows students to grasp meanings in different ways. It also helps to develop their ability and interest.

\section{B. Contructivism in learning fractions}

According to the constructivist concept the child learns when he/she is able to develop a personal representation about an object of reality or content to be taught, through the modification of their knowledge and interpretation of new knowledge integrated into what he/she already possessed. [13].

Goffree [14], mentions educational basis for teaching mathematics, which must be based on solving real-world problems, therefore, specific situations should be designed for the child to develop their own meanings. Creating a model of a real situation will allow that the student investigate the situation and apply this model in the solution of other problems.

Kieren [1], defines the part-whole relationship as a whole that is cut evenly, using the idea of fraction to quantify the relationship between the whole and a designated number of parts. Regarding partition there are situations that derive in activities to divide integers, identify divisible units, obtain different but equivalent representations arising from the sense of identity or of the same, which is basic for the construction of the different meanings of fraction.

Lamon [15], defines the partition as an operation that generates quantity, based on intuitive activity and informal knowledge of the child about equitable partition, consisting in equal parts determination. Such operation has multiple stages: marking objects, cut and clearly indicate the portion that corresponds to each person.

Based on a constructivist approach, the "Didactic Scenarios" represent different application areas of fractions that conducive an atmosphere for peer interaction, where there is exchange of ideas and discussion of their points of views.

\section{Virtual Reality}

Virtual Reality is a technological system, [16] based on the use of computers and other devices, it must meet four characteristics:

Virtual World is the content, or set of features, of a medium that can exist only because of its creator or transmitted in a way that can be shared with others.

Immersion, feeling of being in an environment, is the participants feeling of being in the virtual environment.
Sensory feedback about the virtual world that is presented to the senses of the participants.

Interactivity. The virtual world responds to user actions.

Virtual Stage is any object in an environment, for the purpose of this work is defined as a 3D scenario that has all the characteristics of virtual reality.

\section{EXPERIMENT}

\section{A. Objective}

The aim of the study is to recognize the importance of designing a virtual system to help overcome educational and cognitive difficulties when working with fractions, in distribution situations. The system includes the design of virtual scenarios.

\section{B. Method}

For the development of the teaching proposal through "Virtual Scenarios" for teaching and learning distribution with fractions, an elementary school was chosen belonging to the public education system, located in within the urban area of Mexico City. We worked with a group of third grade, their ages are between 8 and 9 years.

In relation to the virtual system, it was developed to support the teaching of fractions based on 3D virtual scenarios, in order to improve student understanding in this matter. It has two types of different scenarios, the first focuses on the basic concept of the partition in the subject part-whole and was chosen because this issue is critical for learning fractions. The second scenario covers matters related to distribution.

The system was developed web-based because the facilities for updating the various elements of the system, its speed and because is cross-platform. It is based on clientserver architecture in which the load is divided into three parts or layers with clear division of functions: one for the presentation layer of the system or user interface, one for the calculation, where the rules of the platform are located and the other for storage or persistence of users data and learning objects.

In the research various methodological tools were used such as initial and final questionnaires, interviews and teaching activities. This article shows one of the teaching activities, which was the second didactic scenario entitled "The Restaurant", composed of different objects made in blender 2.62 program, designed to recognize partition and distribution strategies as well as the comparison between equivalent fractions.

\section{Implementation of didactic scenario "The Restaurant” \\ Group was organized as follows:}

Virtual Table 1 = 2 people, share 1 pizza. 
Virtual Table 2 = 8 people, share 2 pizzas and then 2 pizzas. Virtual Table $3=6$ people, share 2 pizzas and then 1 pizza. Virtual Table $4=4$ people, share 1 pizza.

Virtual Table $5=3$ people, share 1 pizza.

\section{Virtual Reality System}

The virtual reality system, is to recreate in a computational enviroment the didactic scenario "The Restaurant”, as shown in Figure 1.

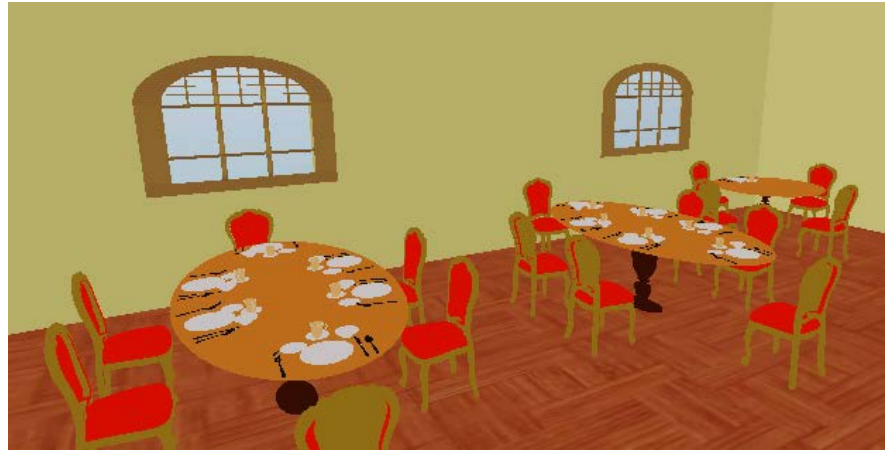

Fig. 1. Didactic Scenario “The Restaurant”

It was based on the idea of Broken Family worked by Streefland, [7] because its use eliminates the abstract quality of participants unnamed and thus student is not only capable of dividing objects easily, but can produced portions linking the names of the participants, and offers a family atmosphere.

We worked with Franco Family, composed by Ms. Laura, Mr. Noé, their sons Paty and Javier, also mentions two family friends Beto and Nancy with whom they share some experiences. The dolls used to represent the family were identical so to differentiate them was placed a label with the name of the character they represented. Figure 2 shows the Franco family and friends.

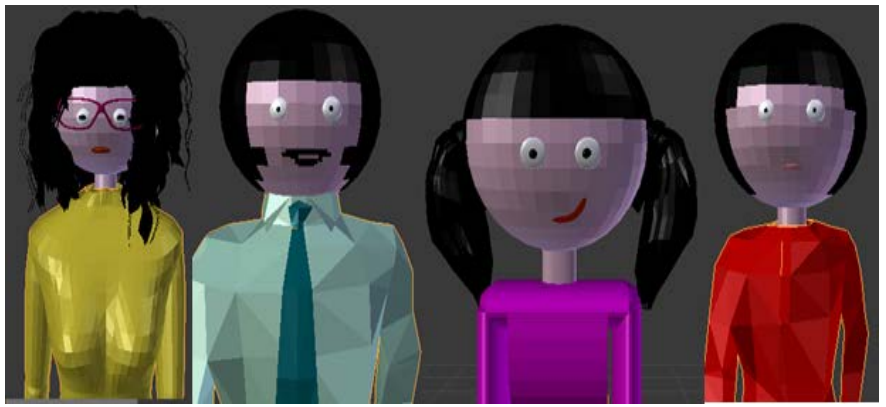

Fig. 2. "Franco Family"

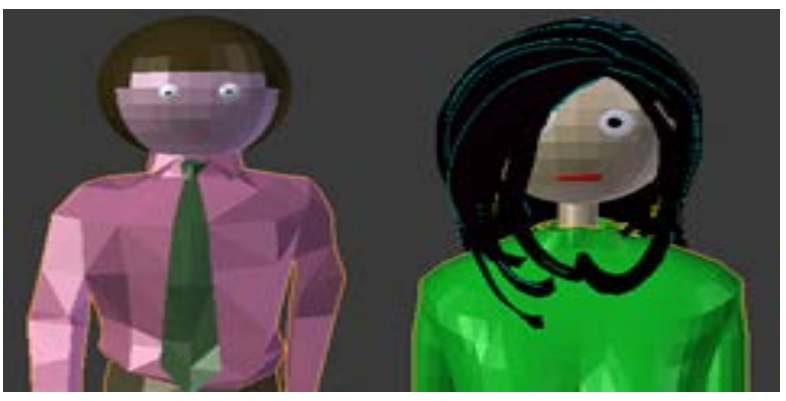

Fig. 3. Franco Family’s Friends

Figure 3 shows the use case diagram of the restaurant scenario in which identifies the actions a user can perform within this scenario with the system components.

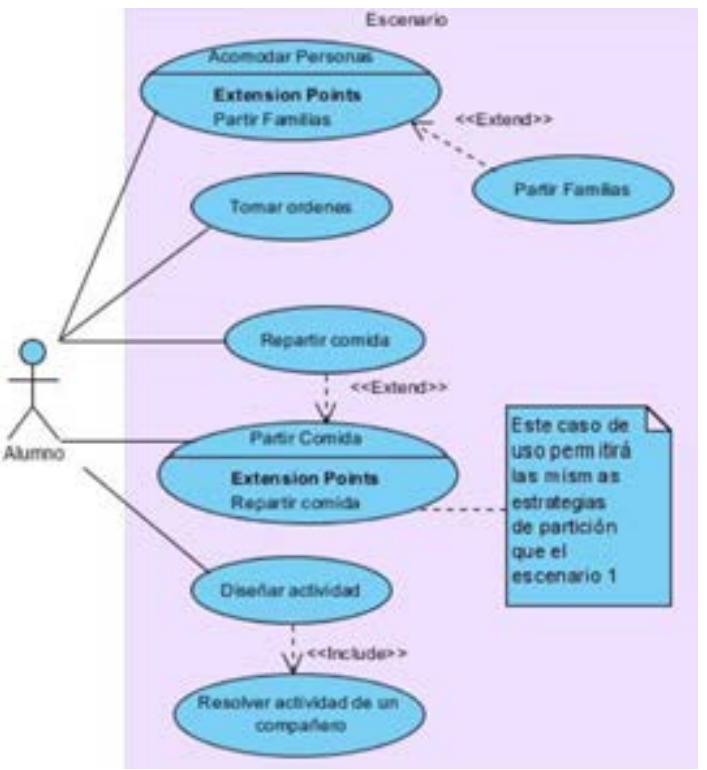

Fig. 4. Use case diagram of the Restaurant scenario

Activities observed: “Accommodating people”, "Take orders" and "Deliver food", but also the user can design an activity.

\section{RESULTS}

The distribution of the number of people at each table and the distribution of objects to deliver generated that the party assigned to each member of the tables 1, 2, 3 and 4, were equivalent. After delivering the pizzas they wrote in a section of the computer system the amount of pizza for each member of their table.

Virtual Table 1 - Jaqueline 1/2

Virtual Table 2 - Aaron 2/4, 1/2 or 4/8

Virtual Table 3 - Fernanda 3/6

Virtual Table 4 - Mariana 2/4

Virtual Table 5 - Angel 1/3

The members of the virtual table 2 were divided into two groups of 4 and each group is dealt two pizzas. So it is up to 
each 2/4, but in writing the fraction that belongs to Aaron, who is one of the members of the table, decide to write two equivalent fractions.

They were asked: "who ate less pizza?" Some answers were "Jaqueline", "the octaves ones". The team of the table 2 responds "no, is the same as has Jaqueline". The members of the table 5 argue that they ate less and compare parts of one of the members of the tables 1 and 5 .

They were then questioned "who ate more?" They said "We (table 2) and the table of Jaqueline", "Not true because we all ate the same, less than that table (table 5)", "because they are equivalent to $1 / 2 "$.

The virtual scenarios allowed that the students simulate being in a restaurant and work with virtual pizzas, cut each one and make the distribution of the slices, thus they were able to compare the numbers and to establish what were equivalent fractions and what were not. This is how they responded to questions.

\section{CONCLUSIONS}

Now that the technology is more accessible to students, interdisciplinary production is important, as is done in this study between Research in Mathematics Education and Computer Science. The union between a scientific discipline with technology, can help the design of educational proposals to improve the teaching and learning of mathematics.

Didactic scenarios help the student to be able to visualize a problem of everyday life in a classroom, plan media like books, try to represent them through images.

With the development of the virtual system to support the teaching of fractions, the student was able to interact more with the objects of the problem presented, and that the system took into account the different ways in which students work or represent a fraction.

The system can cut objects and have them overlay, this helps the student that make cuts, to be able to check that deliveries are made equal before giving an answer to the problem. This was achieved by means of two algorithms, the first one identifies the lines made by the student on the object, in order to know how many objects (parts) will be, with this creates a number of objects equal to the parties, the second eliminates necessary vertices of each object so that remain only the objects traced with lines (cut).

It was noted that the recreational skill development of the students allowed them to build the concepts of partition, distribution and equivalence of fractions, in addition to solving problems.

\section{REFERENCES}

[1] Kieren, T.(1984). Partitioning, equivalence and the construction of rational number ideas. Proceedings of the Fourth International Congress on Mathematical Education. Birkhauser Boston, Inc. E.E.U.U. 30-38.

[2] Ruiz, E. F. (2011). Using an interactive Computer System to Support the task of building the Notions of Ratio and Proportion. Creative education: Scientific Research. 2 (1), 115-120.

[3] Secretaría de Educación Pública. (2011). Plan y Programas de Estudio. México.

[4] Secretaria de Educación Pública. Evaluación Nacional del Logro Académico en Centros Escolares. (ENLACE). [En línea] consultado el 10 de junio de 2011 en la página http://enlace.sep.gob.mx.

[5] Figueras, O. (1996). Juntando partes. Hacia un modelo cognitivo y de competencia en la resolución de problemas de reparto. En: F. Hitt (Ed.), Didáctica. Investigaciones en Matemática Educativa. México: Grupo Editorial Iberoamérica. 173-196.

[6] Freudenthal, H. (1983). Didactical Phenomenology of Mathematical Structures. Holland Dordrechet: D. Reidel Publishing Company.

[7] Streefland, L. (1991) Fractions in realistic mathematics education. Tesis Doctoral publicada por la Kluwer Academic Publishers.Figueras, O. (1996). Juntando partes. Hacia un modelo cognitivo y de competencia en la resolución de problemas de reparto. En: F. Hitt (Ed.), Didáctica. Investigaciones en Matemática Educativa. México: Grupo Editorial Iberoamérica. 173-196.Prieto, A. (2005). El programa educativo nacional Enciclomedia. Retos y perspectivas. En Anuario Educativo Mexicano visión retrospectiva. Bertussi T. Coo. México. UPN.

[8] Prieto, A. (2005). El programa educativo nacional Enciclomedia. Retos y perspectivas. En Anuario Educativo Mexicano visión retrospectiva. Bertussi T. Coo. México. UPN.

[9] Olguín Trejo E. (2009) Estrategias empleadas por los niños en la resolución de problemas de reparto con fracciones. Tesis de Maestría Cinvestav. IPN. Mexico D.F.

[10] Ruiz, H. (2010) La resolución de problemas, los números fraccionarios y la construcción de nociones de equivalencia en quinto grado. Tesis de Maestría Cinvestav. IPN. Mexico D.F.

[11] Harris J. (2008). Las Tecnologías y la Educación en la Edad Temprana; EDUTEKA, Edición 6, recuperado en octubre de 2011 de http://www.eduteka.org/HarrisEdadTemprana.php.

[12] Galbraith, P. y Haines, C. (1998). Disentangling the nexus: attitudes to mathematics and technology in computer learning environment. Educational Studies in Mathematics, 1 (36), 47-56.

[13] Solé, I., Coll, C. (1999). Los profesores y la concepción constructivista. El constructivismo en el aula. Barcelona: Graó.

[14] Goffree, F. (2000). Principios y paradigmas de una educación matemática realista. Matemáticas y educación. Retos y cambios desde una perspectiva internacional, 9 (1). Barcelona: Graó. 151-167.

[15] Lamon, S.(1996). The Developmental of unitizing: its role in children's partitioning strategies. Journal for Research in Mathematics Education, 27(2), 170-193.

[16] Sherman, W. R., Graig, A, B. (2010). Understanding Virtual Reality: Interface, Application, and Design. Massachusetts. Morgan Kaufmann Publishers.

\section{Creative Commons Attribution License 4.0 (Attribution 4.0 International, CC BY 4.0)}

\author{
This article is published under the terms of the Creative \\ Commons Attribution License 4.0 \\ https://creativecommons.org/licenses/by/4.0/deed.en_US
}

